\title{
TANGGUNG JAWAB PENDIDIKAN DALAM PERSPEKTIF PSIKOLOGI AGAMA
}

\author{
Shabri Shaleh Anwar \\ STIT Ar-Risalah Indragiri Hilir \\ e-mail: shabri.shaleh@yahoo.co.id
}

\begin{abstract}
In the perspective of the religion psychology, education is responsible for the students' development. Education in terminology is a conscious effort to change students' attitudes and behavior towards maturity, with one of indicator is the ability to take responsibility and trust. Responsibility is man's consciousness on his/her behavior, whether intentionally or not, and has a sense of meaning embodiment obligations. Responsible ability built through the education process includes responsibility vertically (to The God), horizontal responsibility (to the something outside himself or someone else), and personal responsibility.
\end{abstract}

Keywords: responsibility, education, religion psychology

\begin{abstract}
Abstrak
Pendidikan dalam perspektif psikologi agama memiliki tanggung jawab terhadap perkembangan anak didik. Pendidikan secara terminologi adalah usaha sadar untuk melakukan perubahan sikap dan perilaku kearah kedewasaan, dengan salah satu indikatornya adalah kemampuan memikul tanggung jawab dan amanah. Tanggung jawab adalah kesadaran manusia akan tingkah laku atau perbuatan yang disengaja maupun yang tidak di sengaja, serta memiliki makna perwujudan kesadaran akan kewajibannya. Kemampuan bertanggungjawab yang dibangun melalui proses pendidikan meliputi tanggung jawab vertikal (kepada Tuhan), tanggung jawab horizontal (kepada diluar dirinya,) dan tanggung jawab personal.
\end{abstract}

Kata Kunci: tanggung jawab, pendidikan, psikologi agama

\section{PENDAHULUAN}

Psikologi adalah sebuah bidang ilmu pengetahuan dan ilmu terapan yang mempelajari mengenai perilaku dan fungsi mental manusia secara ilmiah. Para praktisi dalam bidang psikologi disebut para psikolog. Para psikolog berusaha mempelajari peran fungsi mental dalam perilaku individu maupun kelompok, selain juga mempelajari tentang proses fisiologis dan neurobiologis yang mendasari perilaku. ${ }^{1}$

Oleh sebab itu psikologi agama adalah bidang ilmu pengetahuan yang menyelidiki gejala psikologis dengan menggunakan pendekatan agama. Dalam perspektif psikologi agama ada tingkatantingkatan tertentu dalam proses pendidik- an untuk mendapatkan perubahan kedewasaan sikap peserta didik. Semisal pemikiran Maslow tentang Teori Hierarki Kebutuhan Individu sudah dikenal luas, namun aplikasinya untuk kepentingan pendidikan peserta didik di sekolah tampaknya belum mendapat perhatian penuh. Secara ideal, dalam rangka pencapaian perkembangan diri peserta didik, sekolah seyogyanya dapat menyedi-akan dan memenuhi berbagai kebutuhan peserta didiknya. Berikut ini ringkasan tentang beberapa kemungkinan yang bisa dilakukan di sekolah dalam mengaplikasikan teori kebutuhan Maslow.

1. Pemenuhan Kebutuhan Fisiologis:

a. Menyediakan program makan siang yang murah atau bahkan gratis.

\footnotetext{
${ }^{1}$ http://id.wikipedia.org/wiki/Psikologi
} 
b. Menyediakan ruangan kelas dengan kapasitas yang memadai dan temperatur yang tepat.

c. Menyediakan kamar mandi/toilet dalam jumlah yang seimbang.

d. Menyediakan ruangan dan lahan untuk istirahat bagi peserta didik yang representatif.

2. Pemenuhan Kebutuhan Rasa Aman:

a. Sikap guru: menyenangkan, mampu menunjukkan penerimaan terhadap peserta didiknya, dan tidak menunjukkan ancaman atau bersifat menghakimi.

b. Adanya ekspektasi yang konsisten

c. Mengendalikan perilaku peserta didik di kelas/sekolah dengan menerapkan sistem pendisiplinan peserta didik secara adil.

d. Lebih banyak memberikan penguatan perilaku (reinforce-ment) melalui pujian/ganjaran atas segala perilaku positif peserta didik dari pada pemberian hukuman atas perilaku negatif peserta didik.

3. Pemenuhan Kebutuhan Kasih Sayang atau Penerimaan:

a. Hubungan Guru dengan Peserta didik:

1) Guru dapat menampilkan ciri-ciri kepribadian: empatik, peduli dan intereres terhadap peserta didik, sabar, adil, terbuka serta dapat menjadi pendengar yang baik.

2) Guru dapat menerapkan pembelajaran individua dan dapat memahami peserta didiknya (kebutuhan, potensi, minat, karakteristik kepribadian dan latar belakangnya)

3) Guru lebih banyak memberikan komentar dan umpan balik yang positif dari pada yang negatif.

4) Guru dapat menghargai dan menghormati setiap pemikiran, pendapat dan keputusan setiap peserta didiknya.

5) Guru dapat menjadi penolong yang bisa diandalkan dan mem- berikan kepercayaan terhadap peserta didiknya.

b. Hubungan Peserta didik dengan Peserta didik:

1) Sekolah mengembangkan situasi yang memungkinkan terciptanya kerja sama mutualistik dan saling percaya di antara peserta didik

2) Sekolah dapat menyelenggarakan class meeting, melalui berbagai forum, seperti olah raga atau kesenian.

3) Sekolah mengembangkan dis-kusi kelas yang tidak hanya untuk kepentingan pembelajaran.

4) Sekolah mengembangkan tutor sebaya

5) Sekolah mengembangkan bentukbentuk ekstra kurikuler yang beragam.

4. Pemenuhan Kebutuhan Harga Diri:

a. Mengembangkan Harga Diri Peserta didik

1) Mengembangkan pengetahuan baru berdasarkan latar pengetahuan yang dimiliki peserta didiknya (scaffolding).

2) Mengembangkan sistem pembelajaran yang sesuai dengan kebutuhan peserta didik.

3) Memfokuskan pada kekuatan dan aset yang dimiliki setiap peserta didik.

4) Mengembangkan strategi pembelajaran yang bervariasi

5) Selalu siap memberikan bantuan apabila para peserta didik mengalami kesulitan.

6) Melibatkan seluruh peserta didik di kelas untuk berpartisipai dan bertanggung jawab.

7) Ketika harus mendisiplinkan peserta didik, sedapat mengkin dilakukan secara pribadi, tidak di depan umum.

b. Penghargaan dari pihak lain

1) Mengembangkan iklim kelas dan pembelajaran kooperatif dimana setiap peserta didik dapat saling 
menghormati dan mempercayai, tidak saling mencemoohkan.

2) Mengembangkan program "star of the week"

3) Mengembangkan program penghargaan atas pekerjaan, usaha dan prestasi yang diperoleh peserta didik.

4) Mengembangkan kurikulum yang dapat mengantarkan setiap sisiwa untuk memiliki sikap empatik dan menjadi pendengar yang baik.

5) Berusaha melibatkan para peserta didik dalam setiap pengambilan keputusan yang terkait dengan kepentingan para peserta didik itu sendiri.

c. Pengetahuan dan Pemahaman

1) Memberikan kesempatan kepada para peserta didik untuk mengeksplorasi bidang-bidang yang ingin diketahuinya.

2) Menyediakan pembelajaran yang memberikan tantangan intelektual melalui pendekatan discoveryinquiry

3) Menyediakan topik-topik pembelajaran dengan sudut pandang yang beragam

4) Menyediakan kesempatan kepada para peserta didik untuk berfikir filosofis dan berdiskusi.

d. Estetik

1) Menata ruangan kelas secara rapi dan menarik.

2) Menempelkan hal-hal yang menarik dalam dinding ruangan, termasuk di dalamnya memampangkan karya-karya seni peserta didik yang dianggap menarik.

3) Ruangan dicat dengan warnawarna yang menyenangkan.

4) Memelihara sarana dan pra sarana yang ada di sekeliling sekolah.

5) Ruangan yang bersih dan wangi

6) Tersedia taman kelas dan sekolah yang tertata indah.

5. Pemenuhan Kebutuhan Aktualisasi Diri a. Memberikan kesempatan kepada para peserta didik untuk melakukan yang terbaiknya

b. Memberikan kekebasan kepada peserta didik untuk menggali dan menjelajah kemampuan dan potensi yang dimilikinya

c. Menciptakan pembelajaran yang bermakna dikaitkan dengan kehidupan nyata.

d. Perencanaan dan proses pembelajaran yang melibatkan aktivitas meta kognitif peserta didik.

e. Melibatkan peserta didik dalam proyek atau kegiatan "self expressive" dan kreatif. ${ }^{2}$

Akan tetapi dalam konteks psikologi agama bahwa pendidikan itu tidak hanya menyentuh otaknya saja akantetapi juga spiritual. Sebab tanggung jawab manusia yang paling tertinggi adalah tanggung jawabnya kepada Tuhan.

\section{PEMBAHASAN}

\section{Tanggung Jawab Pendidikan}

Tanggung jawab menurut kamus umum Bahasa Indonesia adalah 'keadaan wajib menanggung segala sesuatunya (kalau terjadi apa-apa boleh dituntut, dipersalahkan, diperkarakan dan sebagainya). ${ }^{3}$ 'Tanggung jawab adalah kesadaran manusia akan tingkah laku atau perbuatan yang disengaja maupun yang tidak di sengaja. Tanggung jawab juga berarti berbuat sebagai perwujudan kesadaran akan kewajibannya. Tanggung jawab itu bersifat kodrati, artinya sudah menjadi bagian kehidupan manusia, bahwa setiap manusia pasti dibebani dengan tanggung jawab.

Apabila ia tidak mau bertanggung jawab, maka ada pihak lain yang memaksakan tanggung jawab itu. Dengan demikian tanggung jawab itu dapat dilihat dari dua sisi, yaitu dari sisi pihak yang berbuat dan dari sisi kepentingan

\footnotetext{
${ }^{2}$ www.google.com

${ }^{3}$ KBBI Digital.
} 
pihak lain. Tanggung jawab adalah ciri manusia beradab (berbudaya). Manusia merasa bertanggung jawab karena ia menyadari akibat baik atau buruk perbuatannya itu, dan menyadari pula bahwa pihak lain memerlukan mengabdian atau pengorbanannya. Untuk memperoleh atau me-ningkatkan kesadaran bertanggung jawab perlu ditempuh usaha melalui pendidikan, penyuluhan, keteladanan, dan takwa kepada Tuhan Yang Maha Esa' ${ }^{4}$

Tanggung jawab dapat dibagi kepada tiga bagian yaitu Vertikal, Horizontal dan personal. Pertama, Tanggung jawab secara vertikal adalah Tanggung Jawab Kepada Tuhan. Kedua, Tanggung Jawab secara Horizontal adalah Tanggung Jawab yang berkorelasi dengan hal lain diluar dirinya. Ketiga, Tanggung Jawab Personal adalah tanggung jawab yang menyangkut substansi dirinya sendiri.

Adapun bagian tersebut dapat diuraikan sebagai berikut:

1) Tanggung Jawab Kepada Allah SWT.

Tanggung Jawab kepada Allah adalah tanggung jawab tertinggi dari eksistensi manusia yang beragama. Sebab tujuan utama dari beragama adalah untuk mengabdi kepada Tuhan. Manusia yang memiliki nilai tanggung jawab yang kuat kepada Tuhannya akan memberikan efek positif kepada bentuk tanggung jawab lainnya (kepada makhluk).

Adapun bentuk Tanggung jawab manusia terhadap Tuhan diantaranya adalah:

a) Mengabdikan diri kepada Allah SWT sebagai esensi dari seorang hamba dengan beribadah, beramal shaleh.

http://zaysscremeemo.blogspot.com/2012/06/penge rtian-tanggungjawab.html, diakses 29 September 2014. b) Berpegang Teguh Kepada Agama Allah SWT.

c) Memagang Amanah untuk menjadi Khalifah fil Ardhi.

d) Menjaga kesucian agama, dengan menegakkan Islam dengan berdakwah baik personal maupun individual.

e) Menjaga diri dan keluarga dari jilatan api neraka.

f) Mendidik anak dan ke-luarga dengan pendidikan Agama.

2) Tanggung Jawab Kepada Diri Sendiri

Tanggung jawab kepada diri sendiri merupakan tang-gung jawab personal yang menuntuk motivasi dari dalam diri sendiri. Tanggung jawab personal ini terkadang begitu berat jika tidak dilakukan latihan secara kontinue. Ada banyak orang yang mampu bertanggung jawab kepada orang lain atau hal lain karena adanya dorongan rasa malu atau keterpaksaan, akan tetapi tanggung jawab personal tergantung kepada diri manusia itu sendiri.

Tanggung jawab terhadap diri sendiri menentukan kesadaran setiap orang untuk memenuhi kewajibannya sendiri dalam mengembangkan kepribadian sebagai manusia pribadi. Dengan demikian bisa memecahkan masalah-masalah kemanusiaan mengenai dirinya sendiri menurur sifat dasarnya manusia adalah mahluk bermoral, tetapi manusia juga pribadi. Karena merupakan seorang pribasi maka manusia mempunyai pendapat sendiri, perasaan sendiri, beranganangan sendiri. Sebagai perwujudan dari pendapat, perasaan dan anganangan itu manusia berbuat dan bertindak. Dalam hal ini manusia tidak luput dari kesalahan, kekeliruan, baik yang sengaja maupun yang tidak. $^{5}$

\section{5}

https://putrijayantia.wordpress.com/tag/tanggungjawab-terhadap-diri-sendiri/ 
Adapun bentuk tanggung jawab kepada diri sendiri adalah:

a) Membersihkan Diri baik fisik maupun rohani.

b) Mandiri dalam melakukan hal-hal dalam kehidupan (Membersihkan kamar, taman, mencuci baju sendiri dan lain sebagainya)

c) Mematuhi aturan yang telah dibuat sendiri sebagai contoh siswa atau mahasiswa yang membuat jadwal pekerjaan dan belajar harian, maka ia haruslah bertanggung jawab terhadap apa yang telah ia buat untuk dirinya sendiri.

3) Tanggung Jawab Kepada Tugas (Amanah).

Tugas adalah amanah yang wajib dikerjakan atau yang ditentukan untuk dilakukan atau suatu pekerjaan yg menjadi tanggung jawab seseorang atau dapat juga diartikan dengan suatu perintah yang harus dilaksanakan dengan baik dan benar. Setiap kita memiliki tugasnya masing-masing sesuai dengan levelnya dalam kehidupan sosial. Ayah, ibu, anak, kepala sekolah, direktur, pejabat dan lain sebagainya memiliki tanggung jawab terhadap tugasnya. Se-orang ayah memiliki tang-gung jawab untuk menafkahi anak dan istrinya, istri bertanggung jawab menjaga harta, anak dan keluarganya, kepala sekolah memiliki tanggung jawab terhadap guru dan anak didiknya; semua harus menjalankan sesuai dengan aturan.

Apabila seseorang keluar dari tanggung jawabnya dalam menjalankan tugas maka akan terjadi kerusakan sistem dalam kehidupan atau dalam bahasa agama adalah tidak amanah. Orang yang tidak amanah dalam Islam dikategorikan sebagai

4) Tanggung Jawab Kepada Keluarga

Di dalam kamus Bahasa Indonesia kata 'keluarga' memiliki arti 'ibu dan bapak beserta anak- anaknya; seisi rumah'. 'Keluarga merupakan unit sosial terkecil yang utama dan pertama bagi seorang anak, sebelum ia berkenalan dengan dunia sekitarnya, ia akan berkenalan telebih dahulu dengan situasi keluarga. Pengalaman pergaulan dalam keluarga akan memberikan pengaruh yang sangat besar bagi perkembangan anak untuk masa yang akan datang. Keluargalah yang akan memberikan warna kehidupan seorang anak, baik perilaku, budi pekerti maupun adat kebiasaan sehari-hari. Keluarga jualah tempat dimana seorang anak mendapat tempaan pertama kali yang kemudian menentukan baik buruk kehidupan setelahnya di masyarakat hingga tak salah lagi kalau keluarga adalah elemen penting dalam menentukan baik buruknya masyarakat. ${ }^{7}$

Menurut Badan Penasehat Perkawinan Perselesihan dan Perceraian DKI Jakarta, keluarga adalah masyarakat yang terkecil sekurang-kurangnya terdiri dari pasangan suami atau istri sebagai intinya berikut anak-anak yang lahir dari mereka. Unit terkecil dalam masyarakat yang terdiri dari dua orang lebih tinggal bersama karena ikatan perkawinan atau darah, terdiri dari ayah, ibu, dan anak. ${ }^{8}$

Menurut pandangan sosiologi, keluarga dalam arti luas meliputi semua pihak yang mempunyai hubungan darah dan atau keturunan, sedangkan dalam arti sempit keluar-

\footnotetext{
${ }^{6}$ Tim Penyusun, Kasmus Bahasa Indonesia, op.cit, hal.721-722

${ }^{7}$ Athiyah Al-Abrasy, Dasar-dasar Pokok Pendidikan Islam, (Jakarta: Bulan Bintang, 1993), Cet. 7, h. 133

${ }^{8}$ Abu Ahmadi, Ilmu Sosial Dasar, (Jakarta: PT Rineka Cipta, 1991), Cet. II, hal.104
} 
ga meliputi orang tua dengan anakanaknya. ${ }^{9}$

Menurut Ramayulis keluarga adalah unit pertama dan institusi pertama di dalam masyarakat dimana hubungan-hubungan yang terdapat di dalamnya sebagian besar sifatnya hubungan langsung. Disitulah perkembangan individu dan disitulah terbentuknya tahap-tahap awal perkembangan dan mulai interaksi dengannya, ia memperoleh pengetahuan, keterampilan, minat dan sikap dalam hidup. ${ }^{10}$

Menurut Ibrahim Amini, keluarga adalah orang-orang yang secara terus menerus atau sering tinggal bersama si anak, seperti ayah, ibu, kakek, nenek, saudara laki-laki dan saudara perempuan dan bahkan pembantu rumah tangga, diantara mereka disebabkan mempunyai tanggung jawab menjaga dan memelihara si anak dan yang menyebabkan si anak terlahir ke dunia, mempunyai peranan yang sangat penting dan kewajiban yang lebih besar bagi pendidikan si anak. Menjadi ayah dan ibu tidak hanya cukup dengan melahirkan anak, kedua orang tua dikatakan memiliki kelayakan menjadi ayah dan ibu manakala mereka bersungguhsungguh dalam mendidik anak mereka. Islam menganggap pendidikan sebagai salah satu hak anak, yang jika kedua orang tua melalaikannya berarti mereka telah menzalimi anaknya dan kelak pada hari kiamat mereka dimintai pertanggungjawabannya. Rasulullah SAW bersabda: 'Semua kamu adalah pemimpin, dan setiap pemimpin akan diminta pertanggung jawabannya

${ }^{9}$ Jalaluddin Rakhmat, Keluarga Muslim dalam Masyarakat Moderen, (Bandung: PT. Remaja Rosdakarya, 1994), Cet. 2, hal. 20

10 Ramayulis, Pendidikan Islam dalam Rumah Tangga, (Jakarta: Kalam Mulia, 1987), Cet. 1, hal. 10-11 atas orang yang dipimpinnya'. Seorang penguasa adalah pemimpin dan penanggung jawab rakyatnya. Seorang laki-laki adalah pemimpin dan penanggung jawab keluarganya. Dan seorang wanita adalah pemimpin dan penanggung jawab rumah dan anak-anak suaminya. ${ }^{11}$

Adapun contoh tanggung jawab terhadap keluarga adalah:

a) Ayah bertanggung jawab untuk memberikan rasa aman kepada seluruh anggota keluarganya (anak dan Istri) baik secara kebutuhan primer maupun skunder.

b) Ibu bertanggung jawab mendidik, menjaga, memelihara harta, anakanaknya baik secara jasmani maupun rohani.

c) Anak bertanggung jawab mematuhi dan berbakti kepada orang tuanya dan menjaga nama baik keluarganya.

5) Tanggung Jawab Kepada Masyarakat

Manusia adalah makhluk sosial yang tidak bisa hidup tanpa bantuan manusia lain, sesuai dengan kedudukannya sebagai anggota masyarakat. Karena membutuhkan manusia lain maka ia harus berkomunikasi dengan manusia lain. Dengan demikian manusia sebagai anggota masyarakat tentunya mempunyai tanggung jawab seperti anggota masyarakat yang lain agar dapat melangsungkan hidupnya dalam masyarakat tersebut. Wajarlah apabila segala tingkah laku dan perbuatannya harus dipertanggungjawabkan kepada masyarakat.

Sebagai contoh masyarakat Islam. 'Masyarakat Islam diartikan sebagai sekelompok manusia hidup terjaring kebudayaan Islam, yang diamalkan oleh kelompok itu sebagai kebudayaannya kelompok itu

11 Ibrahim Amini, Agar tidak Salah Mendidik Anak, (Jakarta: Al Huda, 2006), Cet. 1, hal.107-108 
bekerjasama dan hidup berdasarkan prinsip-prinsip Qur'an dan AsSunnah dalam tiap segi kehidupan' ${ }^{12}$

Masyarakat Islam juga diartikan sebagai suatu masyarakat yang universil, yakni tidak rasial, tidak nasional dan tidak pula terbatas di dalam lingkungan batas-batas geografis. Dia terbuka untuk seluruh anak manusia tanpa memandang jenis, atau warna kulit atau bahasa, bahkan juga tidak memandang agama dan keyakinan/aqidah. ${ }^{13}$

Masyarakat dalam pandangan Islam merupakan alat atau sarana untuk melaksanakan ajaran-ajaran Islam yang menyangkut kehidupan bersama. Karena itulah masyarakat harus menjadi dasar kerangka kehidupan duniawi bagi kesatuan dan kerjasama umat menuju adanya suatu pertumbuhan manusia yang mewujudkan persamaan dan keadilan. Pembinaan masyarakat haruslah dimulai dari pribadi-pribadi masingmasing wajib memelihara diri, meningkatkan kualitas hidup, agar dalam hidup wajib memelihara diri, meningkatkan kualitas hidup, agar dalam hidup di tengah masyarakat itu, di samping dirinya berguna bagi masyarakat, ia juga tidak merugikan antara lain.

Islam mengajarkan bahwa kualitas manusia dari suatu segi bisa dipandang dari manfaatnya bagi manusia yang lain. Dengan pandangan mengenai status dan fungsi individu inilah Islam memberikan aturan moral yang lengkap kepadanya. Aturan moral lengkap ini didasarkan pada waktu suatu sistem nilai yang berisi norma-norma yang sama dengan sinar tuntutan religious seperti: ketaqwaan, penyerahan diri,

12 Kaelany HD,Islam dan Aspek-aspek Kemasyarakatan,Bumi Aksara, Jakarta, 1992, hal. 128

${ }^{13}$ Sayid Qutb, Masyarakat Islam, (Bandung: PT. Al-Ma'arif, Bandung, 1978), hal. 70 kebenaran, keadilan, kasih sayang, hikmah, keindahan dan sebagainya. ${ }^{14}$

Fazlur Rahman sebagai-mana yang dikutip oleh Ahmad Syafi'i Ma'arif, bahwa tujuan sentral AlQur'an adalah untuk menciptakan sebuah tata sosial yang mantap dan hidup di muka bumi, yang adil dan diasaskan pada etika. Dalam perspektif Islam apakah individu yang lebih penting ataukah masyarakat, tidak menjadi soal benar, yang jelas antara individu dan masyarakat harus saling bergantung dan saling berkaitan, kita umpamanya tidak akan mengenal individu tanpa masyarakat, yang amat ditekankan Islam ialah perlunya keamanan ontologis bagi binaan sebuah masyarakat dan peradaban di mana prinsip moral transendental menjadi asasnya yang utama. ${ }^{15}$

Kelompok orang yang kehidupannya dalam hubungan manusia dan manusia berasaskan kebudayaan Islam, itulah yang disebut masyarakat Islam, tetapi kelompok orang yang hanya kehidupannya dalam hubungan antara manusia dan Tuhan saja berasaskan Islam, menurut pandangan ilmiah tidak mungkin diistilahkan dengan masyarakat Islam, melainkan masyarakat orangorang Islam. ${ }^{16}$

Maka masyarakat yang hidup dalam masyarakat Islam maka ia bertanggung jawab untuk menjaga hal-hal yang tidak sesuai dengan aturan Islam, atau dengan kata lain ia mesti harus mempertanggung jawabkan perilakunya dalam kehidupan masyarakat Islam secara islami.

Adapun yang harus dilakukan dalam masyarakat Islam sebagai

\footnotetext{
${ }^{14}$ Kaelany HD, op.cit, , hal. 125

15 Ahmad Syafi'i Maarif, Membumikan Islam, (Yogyakarta: Pustaka Pelajar, 1995), hal. 64

16 Sidi Gazalba, Masyarakat Islam Pengantar Sosiologi dan Sosiografi, (Jakarta: Bulan Bintang, 1976), hal. 127
} 
bentuk tanggung jawabnya sebagai makhluk sosial, diantaranya adalah: ${ }^{17}$

1. Meningkatkan kemakmuran Masyarakat dengan Iman dan Taqwa kepada Allah Ta`ala.

Syarat mutlak untuk mendapatkan kemakuran yang sejati dalam ke-hidupan tidak ada cara lain selain melakukan ketundukan kepada Allah Subahanahu wata'ala. Tunduk dalam arti beribadah kepadanya sehingga terjalin hubungan yang harmonis, tunduk juga dalam arti melaksanakan segala perintah dan menjauhi larangannya. Allah Subahanahu wata ala berfirman: Jikalau Sekiranya penduduk negerinegeri beriman dan bertakwa, pastilah Kami akan melimpahkan kepada mereka berkah dari langit dan bumi, tetapi mereka mendustakan (ayat-ayat Kami) itu, Maka Kami siksa mereka disebabkan per-buatannya." (QS. al A'raaf : 96).

2. Menjalin Hubungan Uk-huwah Islamiyah dan Silaturahim.

Menjalin hubungan ukhuwah Islamiyah adalah hubungan antara sesama ummat Islam yang tidak ada hubungan darah. Sementara menjalin silaturahmi adalah hubungan antara ummat islam yang ada hubungan darah atau saudara. Istilah ini sering kali tersalah gunakan dalam pembicaraan dan tulisan-tulisan.

Salah satu ciri dari masyarakat Qur'ani adalah mereka saling menjalin hubungan ukhuwah dan silatu-rahmi dengan baik dan saling perpacu dalam kebaikan tanpa adanya batas anatara si kaya dan si miskin atau lainnya.

${ }^{17}$ Shabri Shaleh Anwar \& Sudirman Anwar, Pendidikan Karakter Qur'ani (Tembilahan: Yayasan Indragiri, 2014), hal.340-347
Firman Allah Subahanhu wata'ala: "Dan Allah melebihkan sebahagian kamu dari sebagian yang lain dalam hal rezki, tetapi orang-orang yang dilebihkan (rezkinya itu) tidak mau memberikan rezki mereka kepada budakbudak yang mereka miliki, agar mereka sama (merasakan) rezki itu. Maka mengapa mereka mengingkari nikmat Allah $^{18}$ ?.” (QS. an-Nahl:71).

"Hai sekalian manusia, bertakwalah kepada Tuhanmu yang telah menciptakan kamu dari seorang diri, dan dari padanya Allah menciptakan isterinya; dan dari pada keduanya Allah memper-kembangbiakkan lakilaki dan perempuan yang banyak. dan bertakwalah kepada Allah yang dengan (mempergunakan) nama-Nya kamu saling meminta satu sama lain, dan (peliharalah) hubungan silaturrahim. Sesungguhnya Allah selalu menjaga dan mengawasi kamu." (QS. anNisaa:1).

Dari Salman bin Amir AdhDhabbi, ia berkata, "Rasulullah SAW bersabda, 'Sedekah kepada orang miskin mendapatkan satu pahala sedekah, dan kepada kerabat mendapatkan dua pahala, (pahala) sedekah dan menyambung silaturahim." (Shahih lighairihi: At-Ta'liq Ar-Raghib (2/32). Al Misykah (1939), Al Irwa" (883).

3. Saling Tolong Menolong dalam Kebaikan.

Masyarakat Qur'ani jauh dari sifat-sifat menyakiti akan tetapi saling tolong menolong dalam kebaikian, inilah sifat yang harus ditanamkan dalam hati anak semenjak dini.

${ }^{18}$ Ayat ini salah satu dasar Ukhuwah dan Persamaaan dalam Islam. 
Dari Jabir RA, dia berkata, "Pada suatu hari, ada dua orang pemuda sedang berkelahi, masing-masing dari kaum Muhajirin dan kaum Anshar. Pemuda Muhajirin itu berteriak, 'Hai kaum Muhajirin, \{berikanlah pembelaan untukku!\}' Pemuda Anshar pun berseru, 'Hai kaum Anshar, \{berikanlah pembelaan untukku!'' Mendengar itu, Rasulullah SAW keluar dan bertanya, 'Ada apa ini? Bukanhkah ini adalah seruan jahiliah?' Orangorang menjawab, "Tidak ya Rasulullah. Sebenarnya tadi ada dua orang pemuda yang berkelahi, yang satu mendorong yang lain." Keudian Rasulul-lah ber-sabda, "Baiklah. Hendaklah seseorang menolong saudaranya sesama muslim yang berbuat zhalim atau yang sedang dizhalimi. Apabila ia berbuat zhalim atau aniaya, maka cegahlah ia dan itu berarti menolongnya. Dan apabila ia dizalimi/ dianiaya, maka tolonglah ia!" (HR. Muslim 8/19).

Dari Abu Hurairah ra, dia berkata: "Rasulullah Sallalahu 'alaih iwasallam telah bersabda: 'Janganlah kalian saling mendengki, saling memfitnah, saling mem-benci, dan saling memusuhi. Janganlah ada seseorang di antara kalian yang berjual beli sesuatu yang masih dalam penawaran muslim lainnya dan jadilah kalian hamba-hamba Allah yang saling bersaudara. Muslim yang satu dengan muslim yang lainnya adalah bersaudara, tidak boleh menyakiti, merendahkan, ataupun menghina. Takwa itu ada di sini \{Rasulullah menunjuk dadanya\} \{Beliau mengucapkannya sebanyak tiga kali\}. Seseorang telah dianggap berbuat jahat apabila ia menghina saudara-nya sesama muslim. Muslim yang satu dengan yang lainnya haram darah-nya, hartanya, dan kehormatan-nya." (HR. Mus-lim 8/11).

4. Saling Nasehat Menasehati Tidak menyakiti saudaranya, baik secara fisik maupun batin. "Demi masa. Sesungguhnya manusia itu benar-benar dalam kerugin. Kecuali orang-orang yang beriman dan mengerjakan amal saleh dan nasehat menasehati supaya mentaati kebenaran dan nasehat-menasehati supaya menetapi kesabaran." (QS. al'Ashr:1-3).

5. Tidak Memarahi dan Mendiamkan Saudaranya Lebih Dari Tiga Hari.

Dari Anas bin Malik RA, bahwasanya Rasulullah SAW telah bersabda, "Janganlah kalian saling membenci, saling dengki, dan saling membelakangi \{memusuhi\}! Tetapi, jadilah kalian hamba-hamba Allah yang bersaudara. Seorang muslim tidak boleh memutuskan hubungan dengan saudaranya sesama muslim lebih dari tiga hari." (HR. Muslim 8/8)

Dari Abu Hurairah RA, bahwasanya Rasulullah SAW telah bersabda: "Jauhilah berprasangka buruk, karena prasangka buruk adalah ucapan yang paling dusta. Janganlah mencari-cari isu; janganlah mencari-cari kesalahan; janganlah saling bersaing; janganlah saling mendengki; janganlah saling memarahi, dan janganlah saling membelakangi \{me-musuhi\}! Tetapi, jadilah kalian hamba-hamba Allah yang bersaudara" (HR. Muslim 8/10).

6. Menutupi Aib Sesama Muslim.

Dari Ibnu Abbas, dari Nabi SAW, beliau bersabda, "Barangsiapa menutupi aib saudaranya 
sesama muslim, maka Allah akan menutupi aibnya di hari Kiamat kelak. Dan, barangsiapa membeberkan aib saudaranya sesama muslim, maka Allah akan membeberkan aib orang ter-sebut sampai Allah memperburuk citra dirinya di rumah-nya." (Shahih: At-Tha'liq Ar-Raghib (3/76) AshShahihah (2341).

7. Menjaga Kehormatan Jiwa dan Harta Saudaranya.

Ahmad bin Muhammad menceritakan kepada kami, Ibnu Al Mubarak mengabarkan kepada kami, dari Abu Bakar AnNahsyali, dari Marzuq Abu Bakar At-Taimi, dari Ummu Darda', dari Abu Darda", bahwa Nabi SAW bersabda, "Barang siapa yang mempertahankan kehormatan saudaranya, maka Allah akan menghalangi api neraka dari wajahnya pada hari Kiamat". Shahih: Ghayah Al Maram (341), Sunan at-Tarmidzi no 1931).

6) Tanggung Jawab Kepada Bangsa dan Negara

Negara adalah wilayah yang didiami oleh suatu penduduk secara tetap dan mempunyai sistem pemerintahan. Setiap individu adalah warga negara suatu negara. Dalam berpikir, berbuat, bertindak, bertingkah laku manusia tidak dapat berbuat semaunya sendiri. Bila perbuatan itu salah, maka ia harus bertanggung jawab kepada negaranya.

Negara adalah suatu wilayah di permukaan bumi yang kekuasaannya baik politik, militer, ekonomi, sosial maupun budayanya diatur oleh pemerintahan yang berada di wilayah tersebut. Negara juga merupakan suatu wilayah yang memiliki suatu sistem atau aturan yang berlaku bagi semua individu di wilayah tersebut, dan berdiri secara independent.
Syarat primer sebuah negara adalah memiliki rakyat, memiliki wilayah, dan memiliki pemerintahan yang berdaulat.

Sedangkan syarat sekundernya adalah mendapat pengakuan dari negara lain. Kata "negara" dipakai beberapa ahli untuk merujuk pada negara berdaulat. Tidak ada kesepakatan khusus mengenai jumlah negara di dunia, karena ada beberapa negara yang masih diperdebatkan kedaulatannya. Ada total 206 negara, dengan 193 negara anggota Perserikatan Bangsa-Bangsa dan 13 lainnya yang kedaulatannya diperdebatkan. Meskipun bukan negara ber-daulat, Inggris, Skotlandia, Wales dan Irlandia Utara (yang tergabung dalam Britania Raya) adalah contoh entitas yang disepakati dan dirujuk sebagai negara. Bekas negara lainnya seperti Bavaria (kini bagian dari Jerman) dan Piedmont (kini bagian dari Italia) tidak akan dirujuk sebagai "negara" dalam kondisi normal, walaupun mereka pernah menjadi sebuah negara yang berdiri sendiri di masa lalu. ${ }^{19}$

Dalam bermasyarakat untuk mencapai tujuan kesejahteraan bersama maka diadakannya kegiatan ber-bangsa dan bernegara. Dimana masing-masing dari kita memiliki tanggung jawab yang sama untuk Negara yakni menjaga persatuan dan kesatuan Negara dengan mengikuti hukum dan tata tertib bernagsa dan bernegara yang diterapkan di Negara tersebut. Salah satu bentuk tanggung jawab bernegara adalah mempertahankan tanah airnya dari para penjajah asing yang ingin merenggut kedaulatannya baik dalam bentuk penjajahan kekayaan negara maupun penjajahan moral.

7) Tanggung Jawab Kepada Lingkungan dan makhluk Hidup

\footnotetext{
${ }^{19}$ http://id.wikipedia.org/wiki/Negara
} 
Kebersihan adalah sebagian dari iman. Oleh sebab itu ummat Islam sendiri memiliki tanggung jawab besar kepada lingkungan hidupnya. Tidak hanya menjaganya akan tetapi memeliharanya agar tetap lestari dan asri.

Tanggung jawab pendidikan adalah untuk membentuk manusia yang dewasa yang di dalam dirinya terkandung nilai tanggung jawab sebagimana dijelaskan di atas.

\section{Solusi}

Dalam proses pembentukan nilai kedewasaan dalam diri peserta didik dibutuhkan penanaman nilai tanggung jawab sejak dini dalam kehidupannya. Mulai dari membangun jiwa mandiri, kebersihan dan lain sebagainya.

\section{SIMPULAN}

Pendidikan dalam perspektif psikologi agama memeliki tanggung jawab terhadap perkembangan anak didik. Dimulai dari proses per-kembangan awal hingga dewasa. Pendidikan secara terminologi adalah usaha sadar untuk melakukan perubahan sikap dan perilaku kearah kedewasaan. Oleh sebab itu indikator dari kedewasaaan adalah tanggung jawab dan amanah. Pendidikan sebagai sebuah institusi memiliki tanggung jawab besar dalam perkembangan sumber daya manusia sebuah negara. Oleh sebab itu urusan pendidikan juga termasuk dalam urusan negara. Membangun manusia yang dewasa bukanlah hal yang mudah, seperti membangun sebuah bangunan, sebab manuia adalah makhluk yang hidup yan gdapat merespon. Oleh sebab itu tanggung jawab pendidikan sangat vital terhadap perkembangan kehidupan manusianya untuk mencapai tujuan dunia dan akhirat.

\section{DAFTAR PUSTAKA}

Athiyah Al-Abrasy, 1993. Dasar-dasar Pokok Pendidikan Islam. Jakarta: Bulan Bintang.

Abu Ahmadi, 1991. Ilmu Sosial Dasar. Jakarta: PT Rineka Cipta.

Ahmad Syafi'i Maarif, 1995. Membumikan Islam. Yogyakarta: Pustaka Pelajar.

Ibrahim Amini, 2006. Agar tidak Salah Mendidik Anak. Jakarta: Al Huda.

Jalaluddin Rakhmat, 1994. Keluarga Muslim dalam Masyarakat Moderen. Bandung: PT. Remaja Rosdakarya.

Kaelany HD, 1992. Islam dan Aspek-aspek Kemasyarakatan. Jakarta: Bumi Aksara.

Ramayulis, 1987. Pendidikan Islam dalam Rumah Tangga. Jakarta: Kalam Mulia.

Sayid Qutb, 1978. Masyarakat Islam. Bandung: PT. Al-Ma'arif.

Sidi Gazalba, 1976. Masyarakat Islam Pengantar Sosiologi dan Sosiografi. Jakarta: Bulan Bintang.

Shabri Shaleh Anwar \& Sudirman Anwar, 2014. Pendidikan Karakter Qur'ani. Tembilahan: Yayasan Indragiri.

\section{Sumber Internet:}

KBBI Digital.

www.google.com

http://id.wikipedia.org/wiki/Psikologi

http://id.wikipedia.org/wiki/Negara

http://zaysscremeemo.blogspot.com/2012/

06/pengertian-tanggungjawab.html

https://putrijayantia.wordpress.com/tag/tan

ggung-jawab-terhadap-diri-sendiri/ 